\title{
The Volhynian (late Middle Miocene) marine fishes and mammals as proxies for the onset of the Eastern Paratethys re-colonisation by vertebrate fauna
}

\author{
Pavel Gol'din, Bogdan Stelian Haiduc, Oleksandr Kovalchuk, Marcin Górka, \\ Pavlo Otryazhyi, Mihai Brânzilă, Elena Ionela Păun, Zoltán Barkaszi, \\ Paul Ţibuleac, and Bogdan Gabriel Răţoi
}

\begin{abstract}
The late Middle Miocene of South-Eastern Europe was the time of major basinwide physical and biogeographical transformations of marine environments with mass extinction and faunal replacement. We examined new material comprising marine fishes and mammals, re-examined earlier finds, and analysed previously published data on the marine vertebrate assemblage that lived along the western and northern edges of the Eastern Paratethys. The studied materials represent marine fishes that belong to at least four families (Clupeidae, Sparidae, Bothidae, and Scombridae), including Sarmatella doljeana, Sparus brusinai, Bothus parvulus, and indeterminate scombroids; true seals (Phocinae), the earliest seal record in the area; small toothed whales of the family Kentriodontidae, including Kentriodon fuchsii, whose presence in the Volhynian is confirmed here, and two other dwarf forms; a bizarre toothed whale Pachyacanthus, the first record in the area between the Vienna Basin and Central Asia; baleen whales, including an indeterminate member of the family Cetotheriidae, and "Archaeocetus fockir". The material found so far hints to a low taxonomic diversity and biogeographical connections to both the synchronous Sarmatian fauna of the Central Paratethys and the later Bessarabian Eastern Paratethyan fauna. The taxonomic composition of the faunal assemblage and its biogeographical connections indicate that it has Central Paratethyan origin and shows an overall west to east direction of gradual dispersal, from the Central Paratethys through the Fore-Carpathian Basin and further east. The taxonomic composition of described Volhynian fish and mammal assemblages supports the idea of faunal connection and transition between the Central and Eastern Paratethys.
\end{abstract}

Gol'din, Pavel, Haiduc, Bogdan Stelian, Kovalchuk, Oleksandr, Górka, Marcin, Otryazhyi, Pavlo, Brânzilă, Mihai, Păun, Elena Ionela, Barkaszi, Zoltán, Tibuleac, Paul, and Răţoi, Bogdan Gabriel. 2020. The Volhynian (late Middle Miocene) marine fishes and mammals as proxies for the onset of the Eastern Paratethys re-colonisation by vertebrate fauna. Palaeontologia Electronica, 23(3):a43. https:// doi.org/10.26879/1091

palaeo-electronica.org/content/2020/3152-the-volhynian-late-middle-miocene

Copyright: September 2020 Paleontological Society.

This is an open access article distributed under the terms of Attribution-NonCommercial-ShareAlike 4.0 International (CC BY-NC-SA 4.0 ), which permits users to copy and redistribute the material in any medium or format, provided it is not used for commercial purposes and the original author and source are credited, with indications if any changes are made. creativecommons.org/licenses/by-nc-sa/4.0/ 
Pavel Gol'din. Schmalhausen Institute of Zoology, National Academy of Sciences of Ukraine, 15 Bohdan Khmelnytsky st., 01030, Kyiv, Ukraine. pavelgoldin412@gmail.com

Bogdan Stelian Haiduc. Alexandru loan Cuza University of laşi, Faculty of Geography and Geology,

Department of Geology, laşi, Romania. haiduc.bogdan91@gmail.com

Oleksandr Kovalchuk. Department of Paleontology, National Museum of Natural History, National

Academy of Sciences of Ukraine, 15 Bohdan Khmelnytsky st., 01030, Kyiv, Ukraine and Department of

Palaeozoology, Institute of Environmental Biology, University of Wroclaw, Sienkiewicza 21, 50-335

Wroclaw, Poland. biologiest@ukr.net

Marcin Górka. Faculty of Geology, University of Warsaw, Al. Żwirki i Wigury 93, 02-089 Warszawa, Poland.

magurka@uw.edu.pl

Pavlo Otryazhyi. Karazin Kharkiv National University, 4 Svobody sq., 61022, Kharkiv, Ukraine.

paveloo108@gmail.com

Mihai Brânzilă. Alexandru Ioan Cuza University of laşi, Faculty of Geography and Geology, Department of

Geology, laşi, Romania.mib@uaic.ro

Elena Ionela Păun. Alexandru loan Cuza University of laşi, Faculty of Geography and Geology,

Department of Geology, laşi, Romania. elenaionelapaun@gmail.com

Zoltán Barkaszi. Department of Paleontology, National Museum of Natural History, National Academy of

Sciences of Ukraine, 15 Bohdan Khmelnytsky st., 01030, Kyiv, Ukraine. zlbarkasi@ukr.net

Paul Ţibuleac. Alexandru Ioan Cuza University of laşi, Faculty of Geography and Geology, Department of Geology, laşi, Romania. paul.tibuleac@uaic.ro

Bogdan Gabriel Răţoi. Alexandru Ioan Cuza University of laşi, Faculty of Geography and Geology,

Department of Geology, laşi, Romania. Corresponding author. bog21rat@gmail.com

Keywords: Paratethys; Miocene; fishes; seals; cetaceans; dispersal

Submission: 21 April 2020. Acceptance: 25 August 2020.

\section{INTRODUCTION}

The late Middle Miocene of South-Eastern Europe was the time of major physical and biogeographic transformations of marine environments (Rögl, 1998; Popov et al., 2004; Palcu et al., 2015, 2017). The Paratethys, a great epicontinental sea of Eurasia, gradually lost its connection with the World Ocean due to the uplift of the AlpineDinarides, Carpathians and Pontides, and broke into a number of inner seas (Rögl, 1998; Popov et al., 2004; Palcu et al., 2015, 2017; Sant et al., 2017). At that time, there were two major basins, the Central and the Eastern Paratethys, with changing contours and environmental conditions. These basins were divided by the uplifting landmass of the Carpathians, and by the smaller ForeCarpathian Basin connected to both basins (Kováč et al., 2017). Their progressing isolation led to the formation of specific local faunas and, respectively, regional stratigraphic units. During the Volhynian age (or Sarmatian s.s.), ca. 12.82 (or 12.65) - 11.8 $\mathrm{Ma}$, which corresponds to the late Serravallian (Palcu et al., 2017), they formed an internally connected basin. Further isolation of the Central Paratethys led to the development of the Pannonian fauna, while in the Eastern Paratethys the endemic
Sarmatian s.l. fauna developed into the assemblages of Bessarabian and, later, Khersonian regional stages.

There are numerous records of marine vertebrates from the Middle/Late Miocene boundary, particularly from the Sarmatian s.s. of the Central Paratethys (Kazár, 2006), and the Bessarabian of the Eastern Paratethys (Brandt, 1873; Koretsky, 2001). However, few localities in the Eastern Paratethys yielded marine vertebrates from pre-Volhynian times. The fossil record of fishes from the Volhynian beds of the Eastern Paratethys is welldocumented (Bogachev, 1929, 1938; Paucă, 1938; lonko, 1954; Bogachev, 1955; Rückert-Ülkümen, 1965; Bannikov, 1986, 1989, 1993; Carnevale et al., 2006; Bannikov, 2009, 2010; Baykina, 2012, 2013a; Bannikov and Kotlyar, 2015; Baykina and Schwarzhans, 2017; Schwarzhans et al., 2017a-d). Bogachev (1955) provided a list of fishes including clupeids and a few other marine fish taxa based on materials from the Volhynian deposits near Amvrosiivka (eastern Ukraine). However, his material is considered problematic (Bannikov, 2010) since it was not described properly and also was probably lost thus unavailable for revision. Macarovici (1970) reported a small fish assemblage from the 
Moldavian Platform; those specimens are redescribed here. Bannikov (2009) described the early Volhynian fish assemblage from Naslavcea, Republic of Moldova, and noticed that it was different from the contemporary fauna of the North Caucasus.

Contrary to fish records, data on Volhynian marine mammals are scarce. A fish-bearing locality and a few toothed whales ("dolphins") were reported from the Caucasus and the Caspian region (Dombrovsky, 1927; Kirpichnikov, 1954; Mchedlidze, 1964; Bannikov, 2009), whereas the western part of the basin was less studied (Kudrin and Tatarinov, 1966). A few cetaceans were reported from the Moldavian Platform in Romania (Macarovici, 1947; Macarovici and Zaharia, 1968; Ionesi and Galan, 1988; Figure 1).

Here we report newly collected marine vertebrate specimens from Romania and Ukraine with their tentative classification, a review of previous finds, a revision of the localities, and respective biogeographical implications.

\section{GEOLOGICAL FRAMEWORK}

The seas of the Central and Eastern Paratethys were interconnected during transgressive events of the Serravallian time, which was repre- sented by the regional stratigraphic units of the Konkian (or late Badenian in the Central Paratethys) and Volhynian (or Sarmatian s.s. in the Central Paratethys) (Figure 2). During the transgressive phases both basins had fully marine conditions; however, they were separated during regressive phases that led to a gradual decrease in salinity with certain salinity crises (Popov et al., 2004; Ter Borgh et al., 2014; Vernyhorova, 2015). The newly discovered and the revised material mostly comes from the Fore-Carpathian Basin (Podolian Platform): from the Ukrainian localities of Kolubaivtsi, Hrushivtsi, and Vilkhovets, and from the Romanian localities of the Eastern Carpathian Foreland (Moldavian Platform): Stăuceni, Leucuşeşti, Stâncești, Basarabi, and Drăguşeni (Figures 1, 2).

A number of other findings and localities were reported from these areas (Khotin: Macarovici, 1947; Khonkivtsi: Hofstein, 1965; Brykiv: Kudrin and Tatarinov, 1966; Ghireni, Cordăreni, Rânghileşti, Mitoc-Prut, Hăneşti, Săveni-Ghireni, Drăguşeni: Macarovici and Zaharia, 1967, 1968; Fălticeni, Voineşti, Erbiceni, Aroneanu, Româneşti: Macarovici, 1970; Darabani: Ionesi and Galan, 1988; Basarabi: Macarovici, 1970, Codrea et al., 2014) (Table S1 in Supplementary Material). The

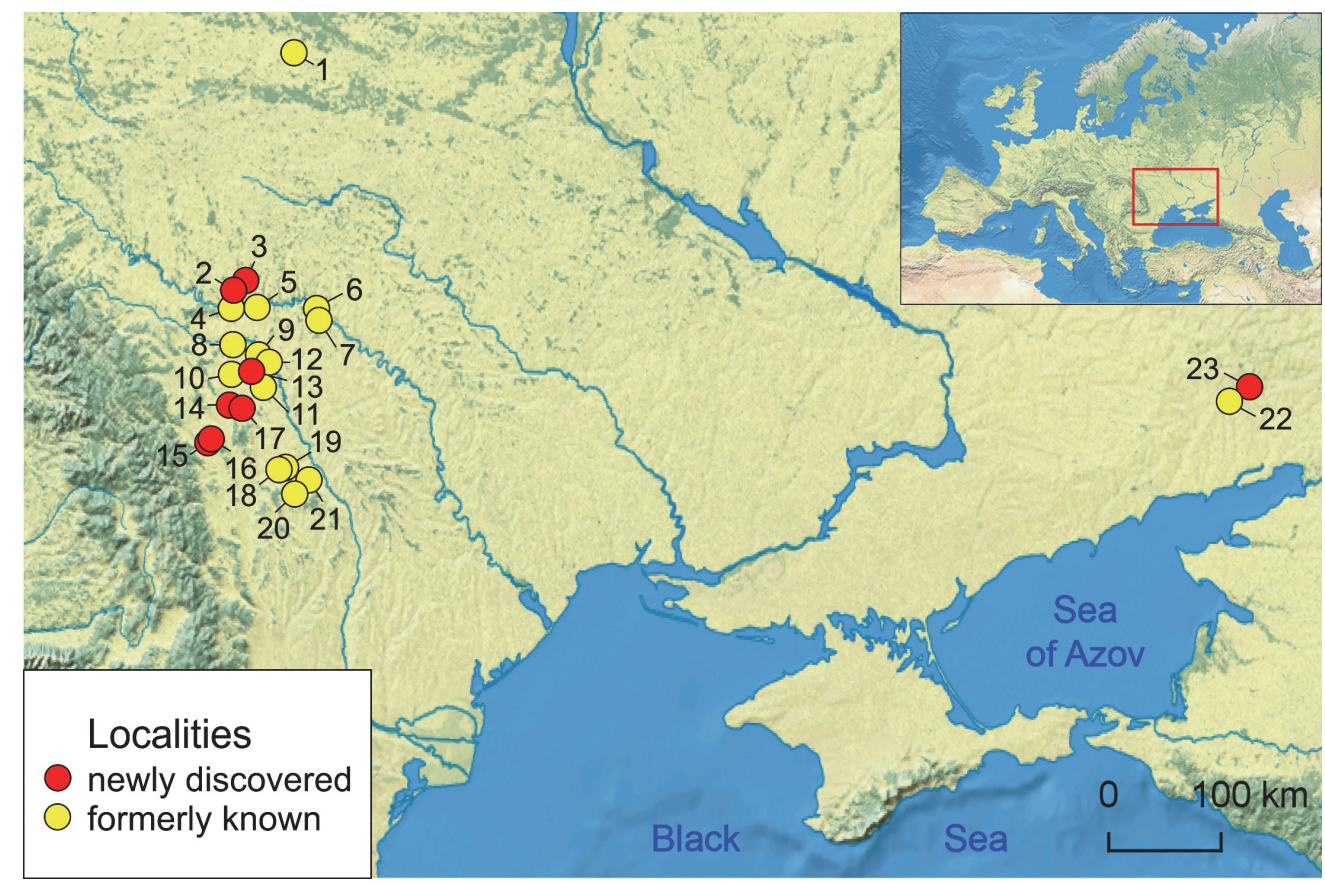

FIGURE 1. Geographic location map of the Volhynian fossil-bearing sites: $\mathbf{1}$ - Brykiv; 2 - Vilkhovets; $\mathbf{3}$ - Kolubaivtsi; 4 - Khotin; 5 - Hrushivtsi; 6 - Khonkivtsi; 7 - Karpov Yar (Naslavcea); 8 - Darabani; 9 - Ghireni; 10 - Cordăreni; 11 Hănești; 12 - Mitoc; 13 - Drăgușeni; 14 - Stâncești; 15 - Leucucești; 16 - Basarabi; 17 - Stăuceni; 18 - Erbiceni; 19 Românești; 20 - Aroneanu; 21 - Voinești; 22 - Amvrosiivka; 23 - Saur-Mohyla. 


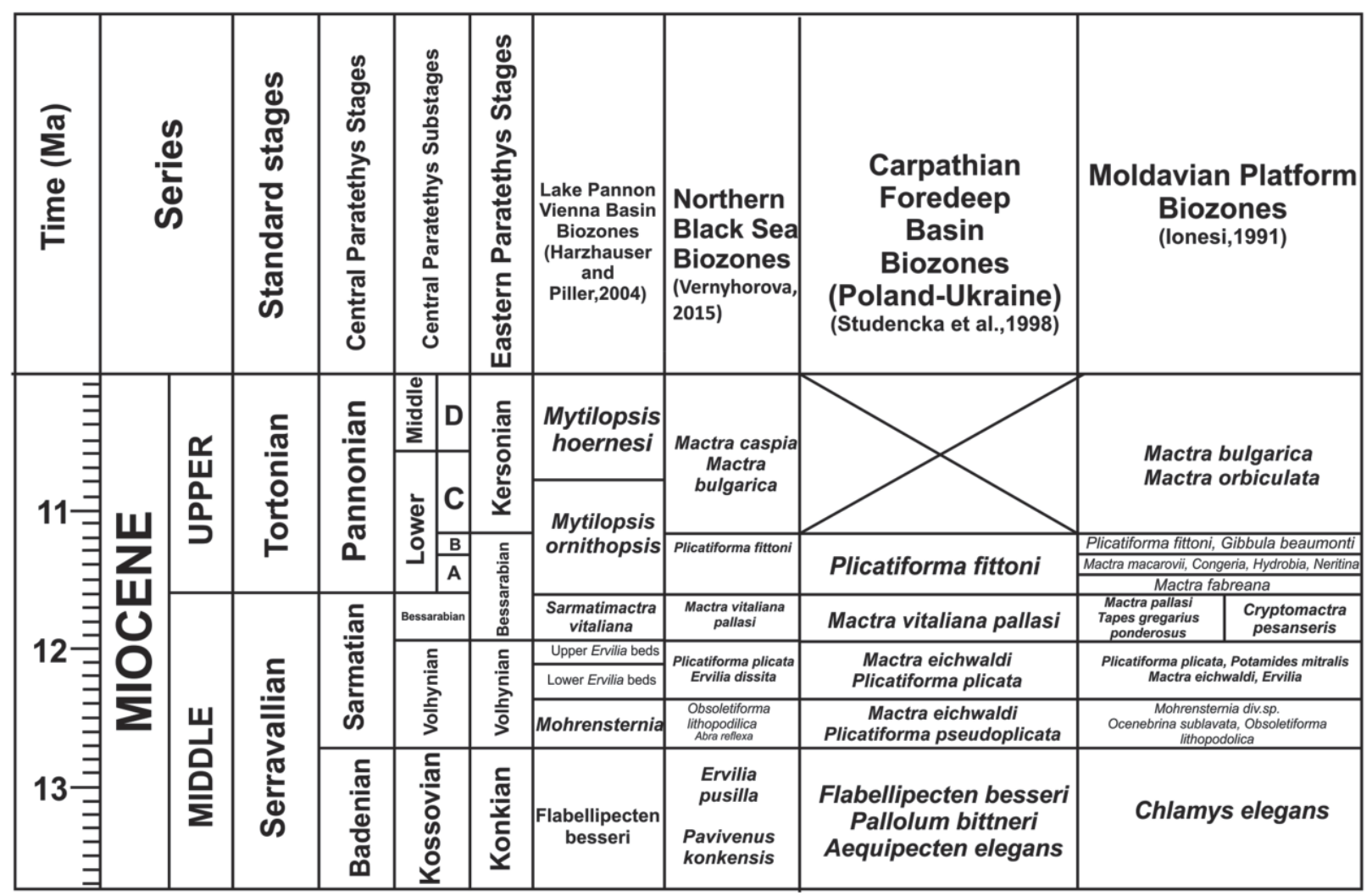

FIGURE 2. Correlation of the Central and Eastern Paratethyan regional stages with standard chronostratigraphy and magnetostratigraphy modified after Harzhauser et al. (2004), Studencka, (1999), lonesi (1991), and Vernyhorova (2015).

studied area evolved as a peripheral foreland basin related to the Carpathian frontal movement owing to the flexural subsidence of a craton under an orogenic belt (Oszczypko and Oszczypko-Clowes, 2012). The deposits here are characterised by higher bed tilts or slightly folded structures as compared to the almost horizontal beds found further east (Grasu et al., 2002). The studied area was predominantly covered by shallow marine and brackish water environments within the Galiczian Gulf (Popov et al., 2004). In addition, Saur-Mohyla locality is situated to the east and represents the northern edge of the Eastern Paratethys (see Figure 1).

\section{GEOLOGICAL SETTING}

The geologically youngest marine vertebrate fossil specimens of Volhynian age were collected from Kolubaivtsi (Ukraine), from south of Stăuceni (Romania), and from Darabani (Romania). The 10 $\mathrm{m}$ thick section in Kolubaivtsi is composed of laminated clays with intercalations of limy clays and marls, and with admixture of phosphorite concretions. Its early Volhynian age was determined from the presence of the bivalves Inaequicostata inopinata and Abra spp. (Jasionowski et al., 2006). In Stăuceni, the $6 \mathrm{~m}$ high outcrop includes compacted or laminated ash-grey clays with fine sand laminae, dated as early Volhynian (Brânzilă, 1999). In Darabani and Drăgușeni, there are several bivalve species (including Inaequicostata inopinata and Obsoletiforma lithopodolica) and foraminifers (Cycloforina karreri ovata, Cycloforina karreri karreri, Elphidiella serena, and Elphidium reginum) indicating the early Volhynian age (Ionesi and Galan, 1988), as well as in the localities reported by Macarovici and Zaharia $(1967,1968)$. The fossil-bearing site in the abandoned quarry near Khonkivtsi (Vinnytsia Oblast, Ukraine) is possibly of the same age, where a $15 \mathrm{~m}$ thick Volhynian marl layer is overlying $20 \mathrm{~cm}$ thick phosphoritebearing sandstones above the laminated Badenian sandstones. Also, the Volhynian marl is overlying the Badenian sandstones further northwards.

The late Volhynian localities include Leucuşeşti, Stâncești, Basarabi, Voineşti, Erbiceni, Aroneanu, and Brykiv. A fish specimen comes from a marl bed drilled by the F. $204 \mathrm{H}$ Antilești borehole at $67.5 \mathrm{~m}$ (ca. $365 \mathrm{~m}$ absolute altitude) in the 
Dealul Nucului (Leucuşeşti), in the foredeep depozone; it is dated as late Volhynian of the FălticeniBoroaia Formation (or Fălticeni Formation) based on the presence of the mollusc assemblage (Țibuleac, 2009).

The locality near Basarabi is where a succession of marl, sand, and thin sandstone beds of the latest Volhynian age are exposed along the Pâraul lui Gheorghe brook (Codrea et al., 2014 and references therein); the vertebrate specimens come from the sandstone layer, which is younger in age than the Dealul Nucului horizon. The Stâncești locality is represented by sandy deposits, dated as late Volhynian based on the mollusc fauna (lonesi, 1968).

The fish assemblage described by Macarovici (1970) from the Moldavian Platform was dated as late Volhynian according to the foraminiferal assemblage identified by Paghida-Trelea (1969). Brykiv in western Ukraine is dated at the same age based on the occurrence of Mactra eichwaldi and Ervilia dissita (Tatarinov, 2000).

Hrushivtsi was reported as a locality where the Volhynian marl succession is overlying Badenian deposits, without further details on dating (Tatarinov, 2000); the fish-bearing bed is devoid of malacofauna. Also, the deposits from Vilkhovets can only be dated as Volhynian, without more precise data. The Saur-Mohyla locality is situated in the easternmost part of Ukraine. The marine mammal specimens found here were collected from a borehole at a depth of 5.4-5.6 $\mathrm{m}$ in 1951, and their age was identified as Volhynian in the field, without details. However, as seen from palaeogeographic reconstructions, this area was flooded by the sea during the late Volhynian time. The nearby locality of Amvrosiivka (Bogachev, 1955) probably is of the same age.

\section{MATERIAL AND METHODS}

The examined material (Tables S1-S3) is housed at the Alexandru loan Cuza University Department of Geology Collections (AICUPM), National Museum of Natural History, National Academy of Sciences of Ukraine (NMNHU-P), Museum of the Faculty of Geology, University of Warsaw, Poland (MWGUW), and Chernivtsi National University, Ukraine (CNU). The newly found material was collected in 2018 by one of the authors $(\mathrm{BH})$ from an open pit in Stăuceni and from Basarabi, as well as by another author (PT) in Leucuceşti at Dealul Nucului (all above-mentioned localities are from Romania). The comparative materials were examined in the Hungarian Natural
History Museum (HNHM) and the Georgian National Museum (GNM).

The material is represented by complete and partial skeletons, isolated bones, and scales. It was identified based on comparative observations in reference collections and published data (Carnevale et al., 2006; Kazár, 2005, 2006; Baykina, 2013a, b; Schwarzhans et al., 2017d). The map of localities was created in QGIS 3.6 using open domain layers (Natural Earth).

\section{SYSTEMATIC PALAEONTOLOGY}

\author{
Class ACTINOPTERYGII sensu Goodrich, 1930 \\ Order CLUPEIFORMES Bleeker, 1859 \\ Family CLUPEIDAE Cuvier, 1817 \\ Genus SARMATELLA Menner, 1949 \\ Sarmatella doljeana (Gorjanović-Kramberger, \\ 1884) \\ Figure 3A-B
}

Material and localities. Two incomplete articulated skeletons; Leucuşeşti, Hrushivtsi.

Description. The anterior part of the body (Figure $3 A$ ) is well preserved; however, many bones were destroyed and are represented by fragments. The body is elongated and laterally compressed. Its dorsal profile is straight, while the abdomen is moderately convex. The head is large (head length $14.1 \mathrm{~mm}$, head depth $9.8 \mathrm{~mm}$, preorbital distance $4.3 \mathrm{~mm}$, postorbital distance $6.5 \mathrm{~mm}$ ). The skull roof is almost straight, and the snout is pointed. The relatively large orbit (orbital diameter $3.3 \mathrm{~mm}$, vertical diameter $2.6 \mathrm{~mm}$ ) is oval. There are two auditory capsules: bulla prootica is 2.3 times larger than bulla pterotica. The mouth is small and terminal. The lower jaw is $7.2 \mathrm{~mm}$ long. It projects beyond the upper jaw and is articulated with the skull behind the anterior orbital margin. The vertebral column extends above the longitudinal axis of the body and consists of elongated vertebrae. The dorsal fin is preceded by 10 supraneuralia. Another specimen (Figure 3B) is a caudal part of the body. The minimum body depth is $3.5 \mathrm{~mm}$. The caudal fin is deeply forked and has 19 principal rays and 10 additional ones. Its skeleton consists of two epurals, six hypurals, and one parhypural fused with the first preural vertebra.

Remarks. The studied specimens share a set of features diagnostic for Sarmatella doljeana (Gorjanović-Kramberger, 1884): the number and relative size of auditory capsules, projection of the lower jaw and the place of its articulation with the skull, the number of supraneuralia, as well as the structure of the caudal fin (Baykina, 2013a). Also, there are a few complete and subcomplete skele- 

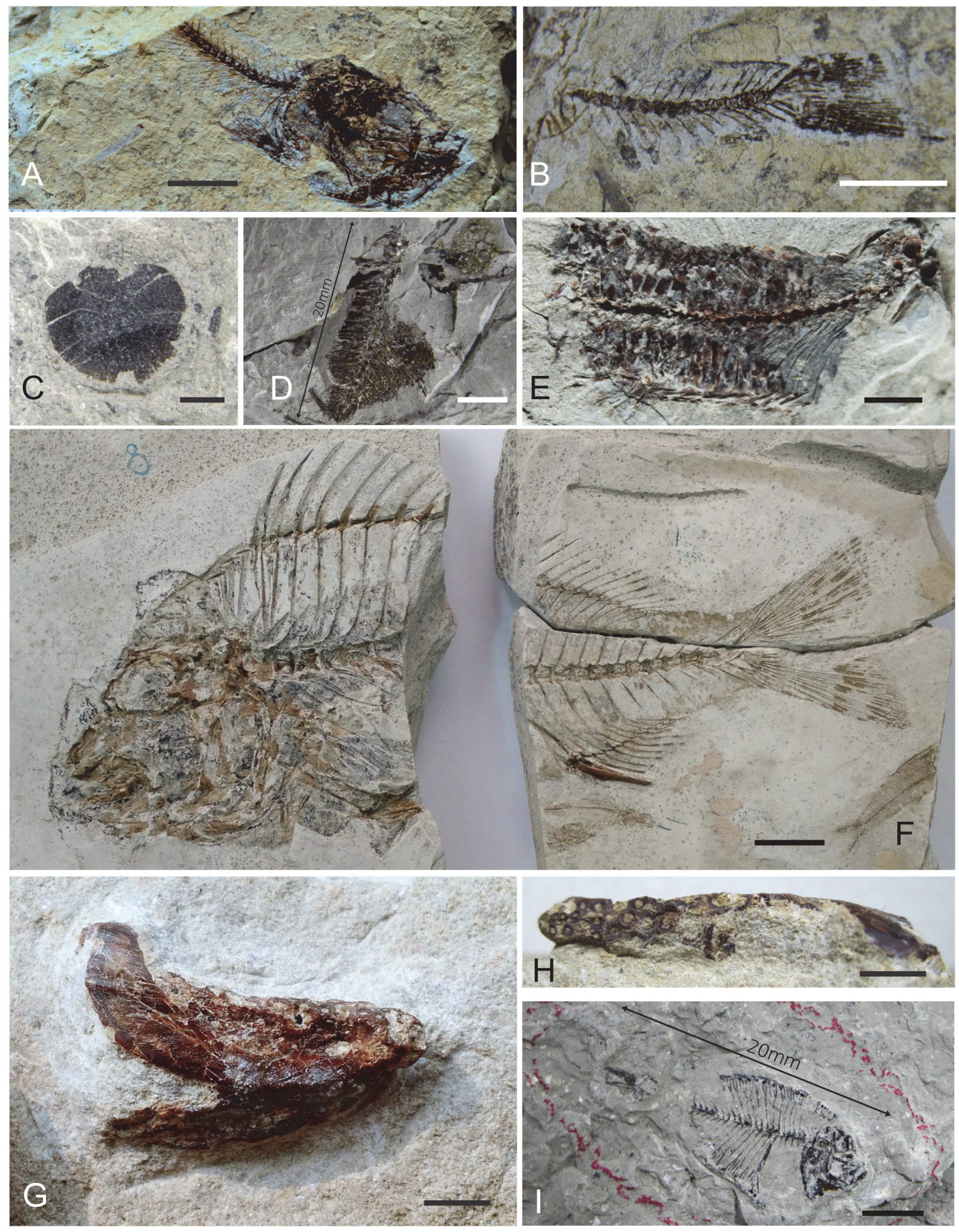

FIGURE 3. Fish remains from the Volhynian beds of Romania and Ukraine: A-B - Sarmatella doljeana (Kramberger, 1884), anterior part of the body (A), and caudal part (B), Leucuşeşti; C - Clupeinae gen. et sp. indet., isolated scale, Voineşti; D-E - Scombroidei indet., caudal part (D), Erbiceni, and middle part of the body (E), Aroneanu; $\mathbf{F}-$ Sparus brusinai (Kramberger, 1882), skeleton, Hrushivtsi; G-H - Sparus cf. brusinai (Kramberger, 1882), right dentary in lateral (G) and dorsal view (H), Pârâul lui Gheorghe; I - Bothus parvulus (Kramberger, 1883), body imprint, Româneşti. Scale bars equal $2 \mathrm{~mm}$ in C, $5 \mathrm{~mm}$ in A-B, D-E, G-I, and $2 \mathrm{~cm}$ in F. 
tons provisionally assigned to Sarmatella doljeana in the collection from Hrushivtsi (Ukraine).

\section{Clupeinae indet.}

Figure 3C

1970 Clupea sp.; Macarovici, pl. 1, fig. 7.

Material and locality. Scale; Voineşti.

Description. A single isolated scale from Voineşti (depth 398-400 m) is scutate in shape; it is $7.0 \mathrm{~mm}$ wide and $6.2 \mathrm{~mm}$ long. The edges of the scale are rounded except for the posterior field, which is moderately crenulated. The anterior field is smooth. There are five vertical primary and secondary grooves arranged symmetrically on the surface of the scale.

Comparison. The scale described is similar to those associated with the posterior body part of "Clupea" sardinites (Szymczyk, 1978, p. 390, table 1 ; p. 395 , figs. $4 d, 5 c$ ) in the number and arrangement of grooves, as well as the shape and lengthwidth ratio of the scale plate.

Remarks. The scale resembles that in herrings in shape and morphology (Lagler, 1947; Szymczyk, 1978). It was assigned to Clupeinae based on the absence of nodules at the middle and lateral fields, unlike those in Alosinae (Peabody, 1928; Szymczyk, 1978). We suggest that the diagnostic importance of clupeid squamation should be limited by subfamily level since comparative studies in case of joint findings of scales and skeletons are absent.

Order PERCIFORMES Bleeker, 1859

Family SPARIDAE Bonaparte, 1832

Genus SPARUS Linnaeus, 1758

Sparus brusinai (Gorjanović-Kramberger, 1882)

Figure 3F

2000 Serranus sp.; Tatarinov.

Material and locality. Almost complete skeleton; Hrushivtsi.

Description. The body is $29 \mathrm{~cm}$ long; its dorsal profile is convex, while the ventral one is rather flattened. Maximum body depth is about $9.5 \mathrm{~cm}(38 \%$ standard length $(\mathrm{SL})$ ) at the beginning of the dorsal fin. The head is noticeably shorter than body depth comprising $30 \% \mathrm{SL}$. The orbital diameter equals $22 \%$ head length. There are small caniniform and molariform teeth arranged in a few rows on dentary. Three large supraneurals are seen anterior to the dorsal fin, which consists of nine preserved spines and 12 soft rays. The number of rays in the pectoral and ventral fins cannot be counted. The anal fin has three spines, the anteriormost of which is the shortest, and the second one is the longest and robust. The forked caudal fin consists of 17 principal rays.

Remarks. The general body shape, the presence of various tooth morphotypes, multi-row dentition, smooth posterior margin of the preopercle, three large supraneuralia, the structure of dorsal, anal, and caudal fins, as well as a number of metric characters (maximum body depth, head length, orbital diameter) allowed us to identify this specimen as Sparus brusinai.

Sparus cf. brusinai (Gorjanović-Kramberger, 1882) Figure 3G-H

Material and locality. Dentary; Basarabi.

Description. The specimen is represented by a broken robust right dentary $26.9 \mathrm{~mm}$ long and 17.8 $\mathrm{mm}$ high. The dental field is convex with traces of sub-circular tooth crown bases on its surface. Teeth are arranged at least in three rows; their diameter varies within $1.5-2.0 \mathrm{~mm}$. The diameter of the teeth in the symphysial part is $1 \mathrm{~mm}$. The symphysial part is slightly isolated, with an oval pore on its outer edge. The symphysis is $4.6 \mathrm{~mm}$ high. The ascending part of the dentary is broad and convex, whereas the descending part is narrow and concave.

Comparison. The studied specimen is generally similar to the dentary of Sparus brusinai (NMNHUP 53/4219, stored in the Department of Palaeontology of the National Museum of Natural History, National Academy of Sciences of Ukraine) described by Tarashchuk (1957) from the Badenian deposits of Dobryvody (western Ukraine), although it is slightly larger.

Remarks. The dentary was assigned to Sparidae, and more precisely to Sparus, due to its shape and multi-row dentition. Proportions of the specimen as well as characteristic tooth bases allowed us to attribute it tentatively to Sparus brusinai (Gorjanović-Kramberger, 1882).

\section{Suborder SCOMBROIDEI Bleeker, 1859 Scombroidei indet. \\ Figure 3D-E}

1970 Caranx sp. (? gracilis Kramberger); Macarovici, pl. 1, fig. 5.

1970 Caranx sp.; Macarovici, pl. 1, fig. 6.

Material and localities. Incomplete skeletons; Aroneanu, Erbiceni, Kolubaivtsi.

Description. There are two incomplete fish body imprints obtained from boreholes. One of them, 36 $\mathrm{mm}$ long, comes from Aroneanu (depth 280-282 $\mathrm{m}$ ) and corresponds to the middle part of the body (Figure 3E). The body is $14.8 \mathrm{~mm}$ high. The vertebral column is located above the body midline, and 
its preserved part consists of 18-20 subrectangular vertebrae associated with long and thin arcuate ribs almost reaching the ventral margin of the abdomen. There are two deep impressions behind the head. The entire body is covered by large scales which are twice as high as long, with rounded edges. The specimen from Erbiceni (depth 230-232 $\mathrm{m}$ ) is represented by the caudal part of the body (Figure 3D). Its dorsal profile is almost straight, whereas the ventral margin is sharply narrowing caudally. The depth ratio of dorsal and ventral portions of the body changes in anteroposterior direction from 1:2 to 1:1. The minimum body depth is $3.2 \mathrm{~mm}$. Vertebrae are connected with long neural and haemal spines oriented backward at $40-45^{\circ}$ to the longitudinal body axis. The anal-fin pterygiophores are robust. Also, the specimen from Kolubaivtsi is represented by a similar, although less preserved, caudal part of the body.

Remarks. All the examined specimens were diagnosed as Scombroidei according to the body shape, vertebrae and distinct squamation represented by high subrectangular scales (Monsch and Bannikov, 2012). We identified them only to suborder level because of poor preservation.

Order PLEURONECTIFORMES Bleeker, 1859

Family BOTHIDAE Regan, 1910

Genus BOTHUS Rafinesque, 1810

Bothus parvulus (Gorjanović-Kramberger, 1884) Figure 31

1970 Caprovesposus sp.; Macarovici, pl. 1, fig. 4.

Material and locality. Incomplete skeleton; Româneşti.

Description. An incomplete body of a sinistral flatfish (SL ca. $16.5 \mathrm{~mm}$ ) with a reduced and partly broken caudal peduncle. The body is oval, $7.6 \mathrm{~mm}$ wide. The head is deep $(5.9 \mathrm{~mm}$ or $128 \%$ head length) and relatively short ( $4.6 \mathrm{~mm} ; 28 \% \mathrm{SL})$. The skull is asymmetrical, and its neurocranial part is roughly triangular. The small mouth (ca. $5 \% \mathrm{SL}$ ) is oblique, directed $60^{\circ}$ to central body axis. The opercle is large and ovoid, and the preopercle is slender and boomerang-shaped. The preserved vertebral column is composed of 35 subrectangular vertebrae, including 10 abdominal and roughly 25 caudal ones. This assumption is based on the length of a vertebra and the total length of the vertebral column. The neural spines are long, and a few anterior abdominal spines bear conspicuous kinks at the bases. Imprints of myorhabdoi are visible at the distal tips of neural and haemal spines. Anterior pterygiophores of the dorsal fin are hourglass shaped. There are 17 principal rays in the caudal fin. The number of rays in other fins is unknown because of incompleteness of the specimen.

Comparison. The specimen described is almost identical to those of Bothus parvulus from the Sarmatian s.s. beds of Dolje (Croatia) in size, body and head proportions (Schwarzhans et al., 2017d, fig. 3, table 2), and in the total number of vertebrae. This specimen differs from the Middle Miocene Bothus sp. from the North Caucasus (Carnevale et al., 2006) in having a larger size, a greater number of precaudal vertebrae, a shorter and deeper head, in the shape of the preopercle, and in the structure of anterior neural spine bases.

Remarks. The specimen is assigned to Pleuronectoidei based on body shape, asymmetrical skull and the dorsal fin extension over the orbital region (Chapleau, 1993; Carnevale et al., 2006). The presence of myorhabdoi and 17 rays in the caudal fin are diagnostic for Bothidae (Hensley, 1977; Hensley and Ahlstrom, 1984; Carnevale et al., 2006; Schwarzhans et al., 2017d). Relationships between separate taxa within this family based on osteological characters remain not completely resolved (Chapleau, 1993; Chanet and Schultz, 1994). However, the shape of anterior dorsal fin pterygiophores and their insertion into cavities of the supraoccipital crest and the presence of robust rectangular haemal spines (Chanet and Sorbini, 2001; Carnevale et al., 2006) support its assignment to the genus Bothus. A boomerang-shaped preopercle and a kink at the base of anterior neural spines of the dorsal fin (Schwarzhans et al., 2017d) indicate that it is Bothus parvulus.

\section{Class MAMMALIA Linnaeus, 1758 \\ Order CARNIVORA Bowdich, 1821 \\ Family PHOCIDAE Gray, 1821 \\ Subfamily PHOCINAE Gray, 1821 \\ Phocinae indet. 1 \\ Figure 4}

Material and locality. Vertebrae, ribs, scapula, and forelimb bones; Kolubaivtsi.

Specific features of anatomy. The material was identified as a member of the Phocinae by the presence of an epicondylar foramen in the humerus (Dewaele et al., 2018a). Meanwhile, it shares a high trochlear crest of the humerus with Monachinae (Koretsky and Grigorescu, 2002; Dewaele et al., 2018b). It is characterised by a smooth distal termination of the long deltopectoral crest reaching the condyle, and a relatively straight posterior margin of the ulna.

Comparison. The specimen has a body size comparable to phocine seals found in later (Bessara- 


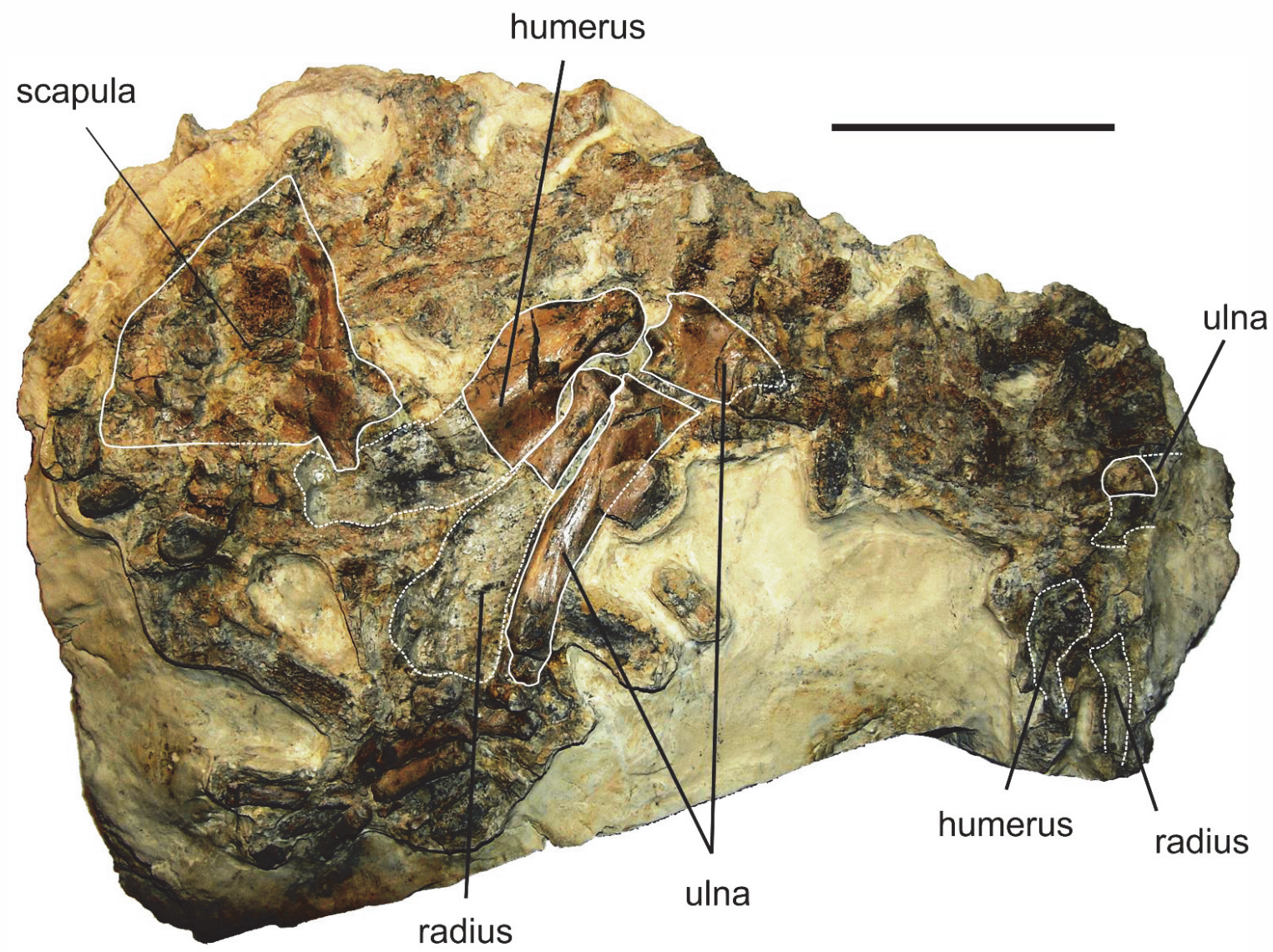

FIGURE 4. The partial skeleton of a true seal (Phocinae indet. 1) from the Volhynian beds of Kolubaivtsi (Ukraine). Scale bar equals $10 \mathrm{~cm}$.

bian) deposits of the Eastern Paratethys. It is larger than Monachopsis pontica, and similar in size to Cryptophoca maeotica (Koretsky, 2001). The humerus has a well-defined trochlear crest larger than that in most of other Paratethyan phocines. The deltoid crest is as long as that in Sarmatonectes sintsovi (Koretsky, 2001).

\section{Phocinae indet. 2}

Figure 5A

Material and locality. Scapula bearing the glenoid fossa, and a caudal vertebra; Stăuceni.

Description. A slender neck of the glenoid portion, a high glenoid fossa, and the slenderness of the scapula support the tentative identification of the fragmentary specimen as Phocinae. The glenoid fossa is deep and the glenoid tubercle is high, the angle between the anterior part and the scapular neck is smaller than in many other seals. The scapular neck is short, and the size of the fragment is small, which may indicate that this specimen represents a young individual.

Comparison. The specimen resembles Praepusa sp. from the Sarmatian s.s. of Hungary and Austria (Koretsky, 2001, 2003) by the structure of glenoid fossa and the anterior edge of the scapula. The glenoid fossa in Pachyphoca chapskii is flatter and the glenoid tubercle is low. This specimen also differs from Nanophoca and Monachopsis by a greater angle between the scapular neck and the anterior edge of the bone.

CETACEA Brisson, 1762

ODONTOCETI Flower, 1867

Family KENTRIODONTIDAE Slijper, 1936 Genus KENTRIODON Kellogg, 1927 Kentriodon fuchsii (Brandt, 1873)

Figures 5B, 6

Material and locality. Partially preserved periotic bone, lumbar vertebra; Stăuceni, Basarabi, Stâncești. 


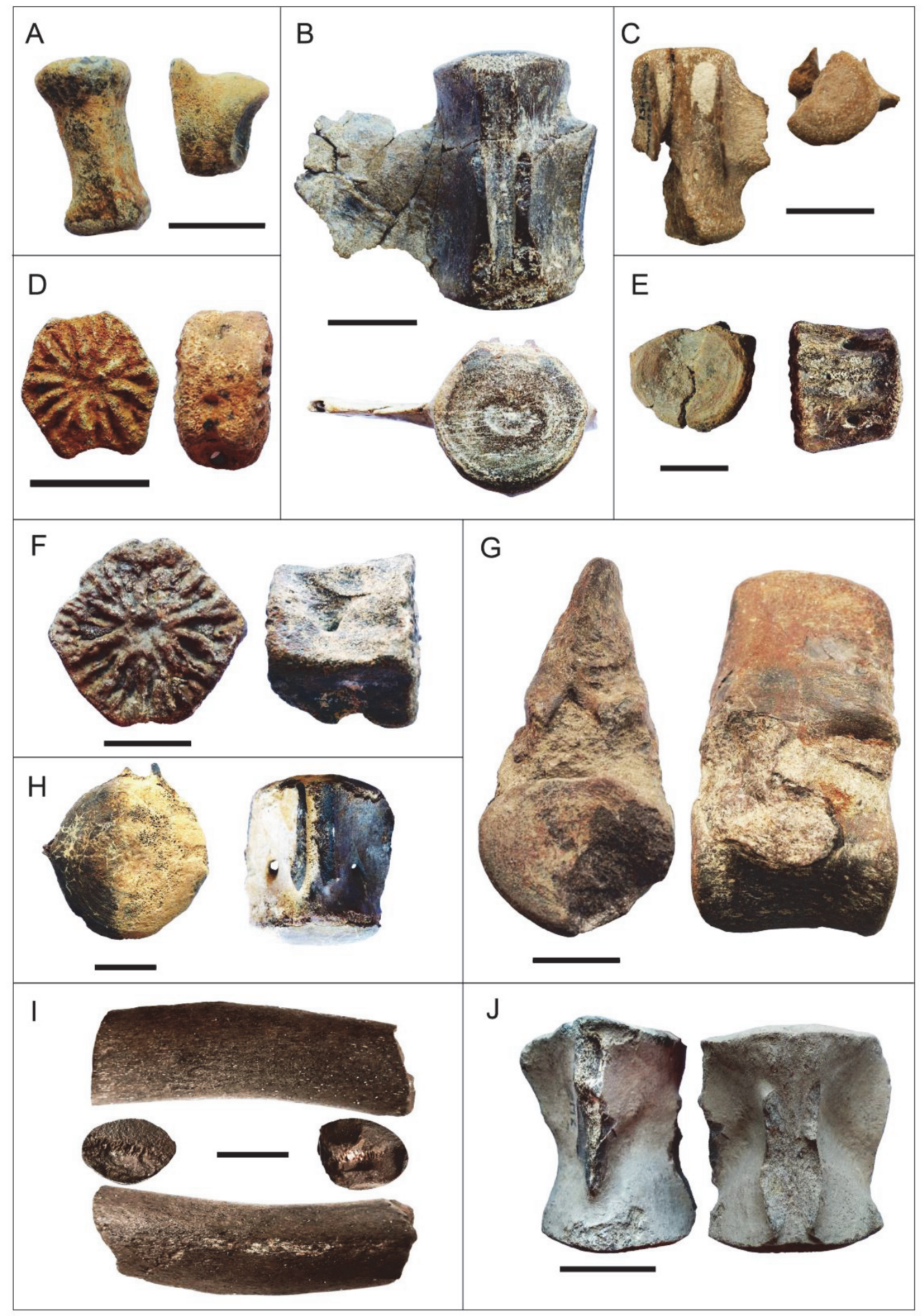

FIGURE 5. Marine mammals from the Volhynian beds of the Moldavian Platform: A - Phocinae indet. 2, scapula and caudal vertebra, Stăuceni; B - Kentriodon fuchsii, a lumbar vertebra, dorsal and posterior view, Basarabi; C - Kentriodontidae indet. 1 (cf. Imerodelphis thabagarii), lumbar vertebra, dorsal and anterior view, Saur-Mohyla; D - Kentriodontidae indet. 2, caudal vertebra, anterior and lateral view, Stăuceni; E - Kentriodontidae indet. 2, thoracic vertebra, anterior view, Stâncești; F - Kentriodontidae indet. 3, caudal vertebra, anterior and lateral view, Stăuceni; G - Pachyacanthus sp., thoracic vertebra, anterior and lateral view, Vilkhovets; $\mathbf{H}$ - Cetotheriidae indet., caudal vertebra, dorsal and lateral view, Stăuceni; I-J - ? Mysticeti indet. (“Archaeocetus fockii”), rib fragment, lateral view and cross-section (I), caudal vertebra (J), dorsal and lateral view, Drăgușeni. Scale bars equal $2 \mathrm{~cm}$ in A-I and $5 \mathrm{~cm}$ in $\mathbf{J}$. 

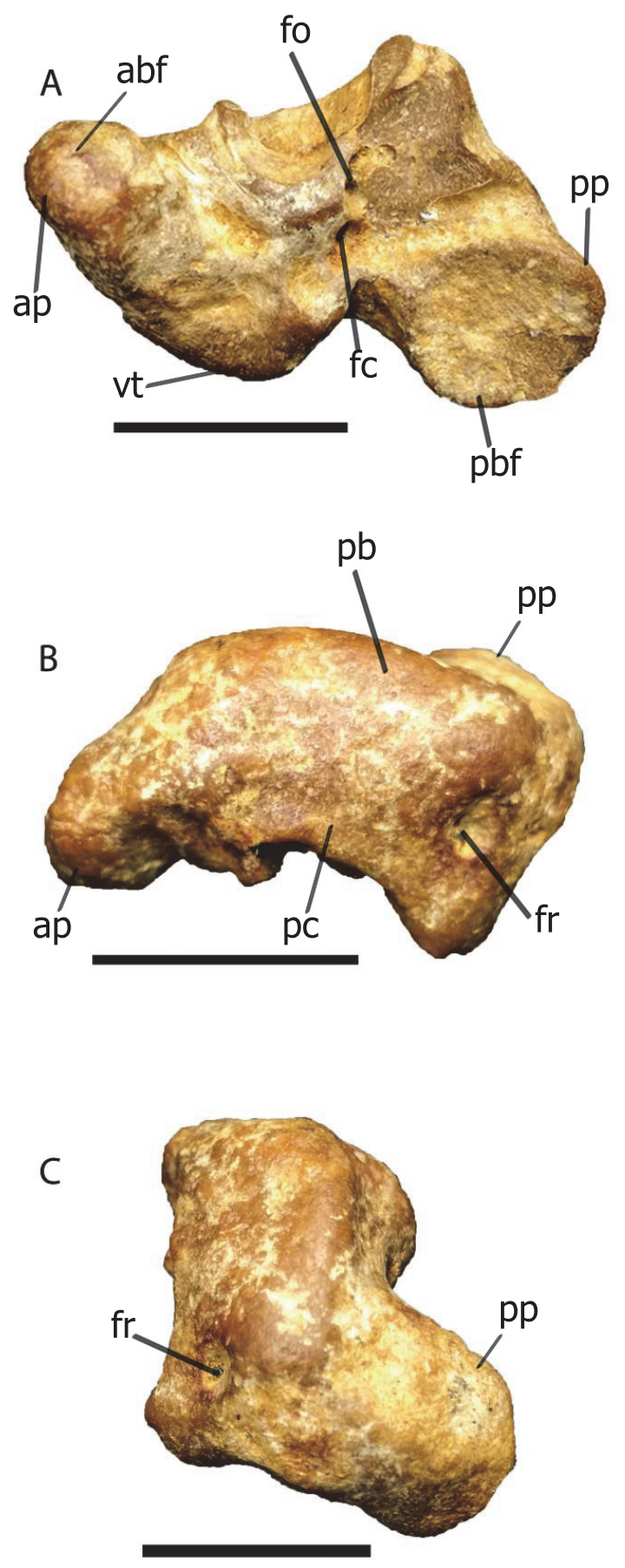

FIGURE 6. The periotic bone of Kentriodon fuchsii from the Volhynian of Stăuceni (Romania) in ventral (A), lateral (B), and posterior view (C). Abbreviations: abf, anterior bullar facet; ap, anterior process; fc, ventral foramen of the facial canal; fo, fenestra ovalis; fr, fenestra rounda; pbf, posterior bullar facet; pc, pars cochlearis; $\mathrm{pb}$, periotic body; pp, posterior process; vt, ventrolateral tuberosity. Scale bars equal $2 \mathrm{~cm}$.
Remarks and comparison. The periotic bone from Stăuceni (Figure 6) shares diagnostic features of Kentriodon fuchsii defined by Kazár (2006): medial bending of the anterior process and lateral bending of the posterior process; short posterior process with pentagonal posterior bullar facet; pars cochlearis (as preserved) broadly joined to the body of the periotic; a large ventrolateral tuberosity; a large eminence dorsal to fenestra rotunda. Also, a few more fragments can be tentatively referred to this taxon. They include elongated vertebrae, which were reported from Ghireni and Cordăreni by Macarovici and Zaharia (1967), Ionesi and Galan (1988), and newly found lumbar and caudal vertebrae, matching the original description of Kentriodon fuchsii (Brandt, 1873). The ulna reported by Codrea et al. (2014) from Basarabi also corresponds to the original description of Kentriodon fuchsii (Brandt, 1873). There are a few issues preventing clear attribution of vertebrae: size variation across the vertebrae; all the specimens are disarticulated and none of them is associated with the periotic bone; Kentriodon fuchsii itself needs redescription and at the end can be split into a few taxa (Kazár, 2006). Another dwarf kentriodontid of this morphotype but smaller than K. fuchsii is Imerodelphis thabagarii.

Kentriodontidae indet. 1

(cf. Imerodelphis thabagarii Mchedlidze, 1964) Figure 5C

Material and locality. Three small and long lumbar vertebrae; Saur-Mohyla.

Comparison. A kentriodontid of this morphotype and size is Imerodelphis thabagarii from the Volhynian of Georgia (Mchedlidze, 1964). A vertebra identified earlier by Macarovici and Zaharia (1967) as Phocaena euxinica has similar size and proportions and, therefore, may represent this or a closely related taxon. However, the type material of Phocaena euxinica does not include vertebrae (Nordmann, 1860) and requires further revision.

\section{? Kentriodontidae indet. 2 \\ Figure 5D-E}

Material and localities. Two thoracic and caudal vertebrae; Stăuceni, Stâncești.

Description and comparison. This is an unusually derived morphotype characterised by extremely short vertebral centra, mostly recorded in modern delphinids (Buchholtz, 2001). The dwarf size of the specimens resembles Microphocaena podolica from the Volhynian of Brykiv (Ukraine), which is known only from its cranium. Notably, $M$. podolica is the only previously known Volhynian 
cetacean from the Fore-Carpathian Basin. Periotic bones from a few dwarf kentriodontids were also reported earlier from the Vienna Basin (Kazár, 2006).

\section{? Kentriodontidae indet. 3 \\ Figure 5F}

Material and localities. Two relatively large and short caudal vertebrae; Stăuceni, Saur-Mohyla.

Description and comparison. Both specimens are characterised by a derived shape of centra, which are as short as high (Figure 5F), and, therefore, are similar to modern delphinids (Buchholtz, 2001). They resemble those of Sophianaecetus commenticius (Kazár, 2005) or "Heterodelphis" leiodontus (Papp, 1905), both from the Sarmatian s.s. of the Central Paratethys. Another similar vertebra from Mitoc-Prut was reported by Macarovici and Zaharia (1967).

Family PLATANISTIDAE Gray, 1846

Genus PACHYACANTHUS Brandt, 1871 Pachyacanthus sp.

Figure 5G

Material and locality. Thoracic vertebra and a partial rib; Vilkhovets.

Description. The vertebra shows lateral pachyosteosclerotic swelling of the spine distinct for this taxon, and the rib is strongly pachyosteosclerotic. This is the first record for Pachyacanthus in the Fore-Carpathian Basin: before it was only recorded in the Vienna Basin and adjoining areas of the Central Paratethys and at the eastern edge of the Eastern Paratethys (Mangyshlak Peninsula, Kazakhstan) (Dombrovsky, 1927; Kazár, 2010).

MYSTICETI Flower, 1864

Family CETOTHERIIDAE Brandt, 1872

Cetotheriidae indet.

Figure $5 \mathrm{H}$

Material and localities. Caudal vertebra; Stăuceni, Kolubaivtsi.

Description. The new material from Stăuceni is represented by a caudal vertebra, which is assigned to Cetotheriidae due to its slight pachyosteosclerosis, a specific trait, which is shared only by that lineage during the late Middle Miocene. In dorsal view, the conical short vertebra has two lateral vascular foramina. The vertebra is similar in size to those of Cetotherium riabinini, a $3 \mathrm{~m}$ long whale (Gol'din et al., 2014). The specimen from Kolubaivtsi is a rib fragment, $3 \mathrm{~cm}$ wide, with developed pachyostosis and strong osteosclerosis, a distinct feature of the Cetotheriinae from the Eastern Paratethys (Gol'din and Startsev, 2017), also shared by Otradnocetus, a stem member of Cetotherioidea (Gol'din, 2018).

Comparison. There is a vertebra reported by Macarovici (1947) from Săveni-Ghireni, and two more vertebrae reported by Macarovici and Zaharia (1967) from Mitoc-Prut, identified by them as Cetotherium priscum: all of the specimens share pachyosteoclerosis and small size, both typical for Cetotheriinae. Also, a similar vertebra was reported by Codrea (2006) from the Volhynian deposits of Thaga (Romania) in the Central Paratethys. A small, short pachyosteoclerotic lumbar vertebra of Cetotheriidae indet. also comes from Kaisersteibruch (Austria), a Badenian-Sarmatian locality in the Central Paratethys (Kazár, 2006). A small baleen whale from Khonkivtsi reported by Hofstein (1965) (temporarily unavailable for study) could belong to this family based on its extremely small size, short and high vertebrae: the centrum of the longest vertebra, the first caudal one, is $70 \mathrm{~mm}$ long, $70 \mathrm{~mm}$ wide and $70 \mathrm{~mm}$ high. Also, it is different from Ciuciulea davidi (Gol'din, 2018) and ? Parietobalaena sp. from the Central Paratethys (Gol'din and Radović, 2018) in having short lumbar vertebrae, a derived trait observed in Late Miocene cetotheriids. Meanwhile, its vertebrae are not pachyosteosclerotic, unlike those of the Paratethyan cetotheriines. Thus, it could represent a hitherto unknown dwarf mysticete taxon.

? Mysticeti indet.

Figure 5I, J

Material and locality. An osteosclerotic rib fragment without signs of pachyostosis; Drăguşeni.

Remarks. Long caudal vertebrae reported as "Archaeocetus fockir" by Macarovici (1947) from Khotin, Macarovici and Zaharia (1967) and by Macarovici and Zaharia (1968) from Hăneşti and Ghireni belong to this taxon. Similar specimens were described from the Sarmatian s.s. of the Central Paratethys. None of the postcranial elements can be firmly associated with cranial specimens and, therefore, the specimens cannot be assigned to any particular taxonomic unit. Besides, this type of vertebral anatomy is plesiomorphic for cetaceans and does not have any taxonomic value. Among Sarmatian cetaceans, a similar anatomy was recorded for "Mesocetus" agrami (Van Beneden, 1884).

\section{DISCUSSION}

The new records of the Volhynian fish fauna from Romania and Ukraine include five taxa representing four families (Sarmatella doljeana, Sparus 
brusinai, Bothus parvulus, Clupeinae indet., and Scombroidei indet.). Sarmatella doljeana was a common member of the Sarmatian s.s. fauna of Croatia (Gorjanović-Kramberger, 1884), Serbia (Anđelković, 1962, 1989), and Turkey (RückertÜlkümen, 1960), and it was recorded from Romanian localities earlier (Baykina, 2013a). Sparus brusinai was previously reported from the Sarmatian s.s. deposits of Croatia, Serbia, Turkey, Moldova, and Azerbaijan (Bannikov, 2010). Tarashchuk (1957) described it from the Badenian of western Ukraine as Pagellus erythrinus (revised by Bannikov, 2010; see Šoster and Kovalchuk, 2016). The flatfish Bothus parvulus was also recorded from the Sarmatian s.s. of Croatia (Schwarzhans et al., 2017d). Therefore, all the fish taxa are shared with the Central Paratethys, and most of them are also shared with other sub-areas of the Eastern Paratethys where they are represented by more recent records (Kovalchuk et al., 2019).

The Volhynian marine mammals of the region are represented by cetaceans (at least five toothed and two baleen whales) and true seals. All of the cetaceans had small body size similar to those reported from the region (Gol'din et al., 2014; Gol'din and Radović, 2018). The cetacean assemblage from the Fore-Carpathian Basin is similar to that from the Sarmatian s.s. of the Central Paratethys (Codrea, 2006; Grigorescu and Kazár, 2006; Kazár, 2006; Gol'din and Radović, 2018), sharing its characteristic taxa such as Kentriodon fuchsii and Pachyacanthus sp., although less diverse, and is different from Volhynian faunas of the other parts of the Eastern Paratethys. In addition to cetaceans, the assemblage described here also includes seals, which represent a remarkable element of the fauna. True seals (Phocidae) are known from the Early Miocene of the Mediterranean region and from the Middle Miocene of the North Atlantic (Koretsky, 2001; Dewaele et al., 2018a, 2018b). In the Central Paratethys, seal remains were found both in Badenian (Devinophoca; Koretsky and Holec, 2002) and Sarmatian s.s. deposits (Praepusa; Koretsky, 2003). However, in the Eastern Paratethys, numerous seals were recorded in the later, Bessarabian, deposits but not in the earlier Miocene strata (Koretsky, 2001). In total, the Volhynian marine mammalian assemblage is similar to that from the subsequent Bessarabian stage of the Eastern Paratethys, but it is less diverse.

Grigorescu and Kazár (2006) suggested that the Central Paratethys was recolonised by the Sarmatian mammalian fauna from the Eastern Para- tethys after the Badenian/Sarmatian extinction event. As seen from this study, the earliest Sarmatian fauna of the Eastern Paratethys was less diverse and less abundant than the Central Paratethyan fauna of the same age, and in the early Volhynian it was mostly concentrated in the ForeCarpathian Basin, the region connected both with the Central and Eastern Paratethys (Kováč et al., 2017). Only the easternmost localities in the Central Paratethys yielded a different marine vertebrate fauna, e.g., in the Caucasus (Bannikov, 2009), or in younger deposits (Mchedlidze, 1964). Also, the Sarmatian fauna studied here includes taxa absent from the earlier Middle Miocene deposits of the Eastern Paratethys but present in the Mediterranean or Atlantic, e.g. Kentriodon or Phocinae.

Sparus brusinai and Cetotheriidae whales, on the contrary, are known from the Badenian of the Fore-Carpathian Basin (Bannikov, 2010; Gol'din, 2018). Meanwhile, the younger, Bessarabian fauna of the whole Eastern Paratethys is abundant, diverse, and similar to the earlier fauna of the Central Paratethys and Fore-Carpathian Basin. Importantly, the faunal assemblage described here is typical for a marine environment. Most of the fishes studied here (Sarmatella, scombroids, Sparus) are euryhaline, although they require normal marine conditions for spawning (Bannikov, 2009; Baykina, 2013). Bothus is a stenohaline genus intolerant of low water salinity (Carnevale et al., 2006). Therefore, most of the Volhynian fauna can be only of marine origin and came from an area with stable marine conditions. Thus, some elements of the Volhynian marine vertebrate fauna found in the Eastern Paratethys had likely originated in the Badenian of the Central Paratethys (Figure 7) (Palcu et al., 2015, 2017). Some of its representatives (e.g., Cetotheriidae) could survive the Badenian/Sarmatian extinction event in the ForeCarpathian Basin and subsequently disperse to the Sarmatian seas of both the Central and Eastern Paratethys. The Volhynian vertebrate fauna can be regarded as transitional between the Sarmatian s.s. fauna of the Central Paratethys and the subsequent Bessarabian fauna of the Eastern Paratethys. However, this was not the sole trend in the development of the Volhynian fauna. For example, some elements of the endemic fish fauna are recorded in the Eastern Paratethys from the Konkian and then the endemism accelerated in the Volhynian (Carnevale et al., 2006; Bannikov, 2010; Schwarzhans et al., 2017a-d). 


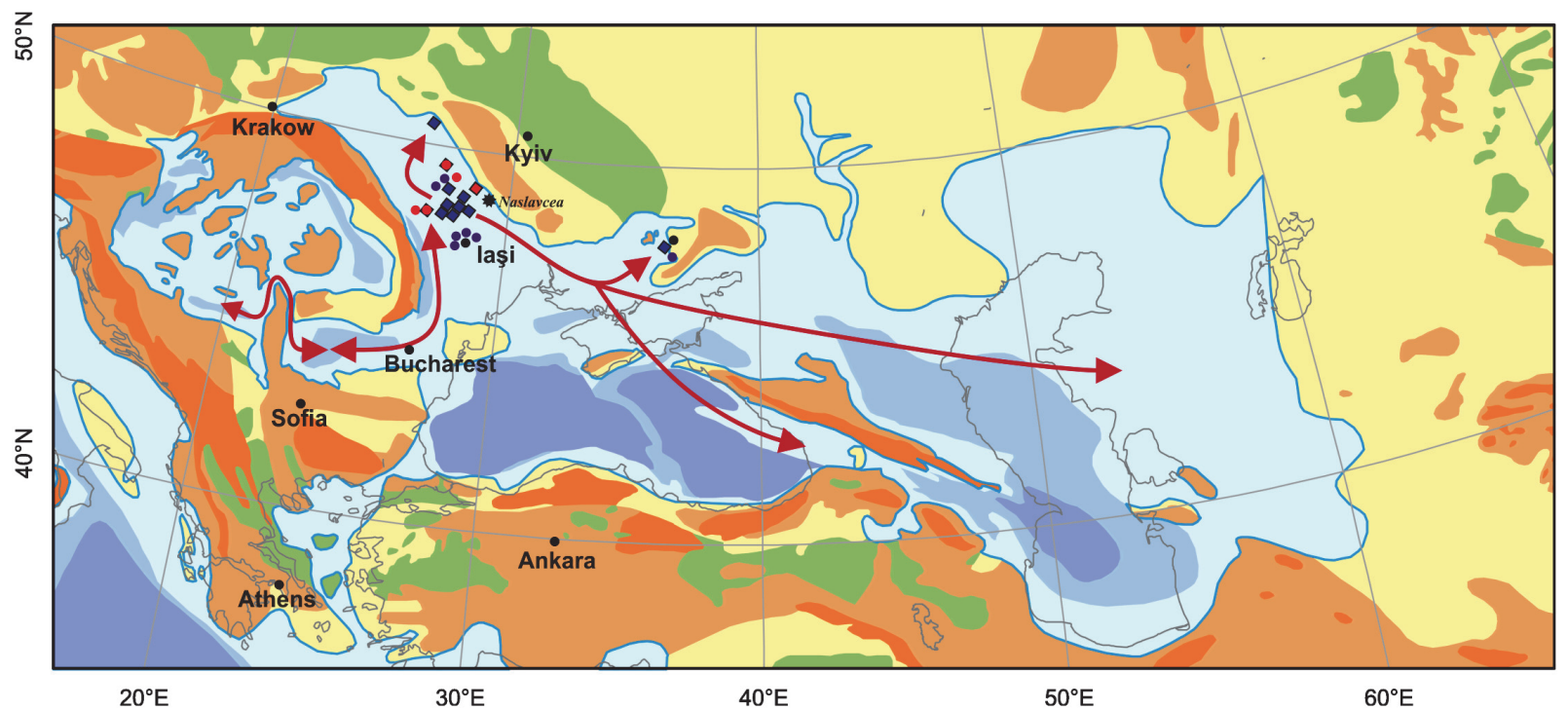

FIGURE 7. Suggested scheme of marine vertebrate fauna dispersal in the Eastern Paratethys during the Volhynian age (modified after Schneider et al., 2013).

Both marine fish and mammal taxa show the tendency toward a decrease in body size. In particular, marine mammals are represented only by small-sized taxa including a dwarf toothed whale. Notably, Microphocaena podolica (Kudrin and Tatarinov, 1966) from the Volhynian of the Eastern Paratethys (Brykiv) was among the smallest cetaceans in history, ca. $80-90 \mathrm{~cm}$ in total length (Gol'din, 2016). In addition, unusual reduction of the number of vertebrae in some fishes, mentioned by Bogachev (1955) and Carnevale et al. (2006), is also seen in our material. This dwarfism is shared by Sarmatian s.s. marine mammals of the Central Paratethys (Gol'din and Radović, 2018). Diminishing body size of top predators is a well-known effect in isolated and marginal seas (Perrin, 1984; Shackell et al., 2010). This is an additional argument for the Central Paratethyan origin of some members of the Volhynian Eastern Paratethyan fauna. During the Late Miocene, a restricted marine environment prevailed in the Eastern Paratethys (Bratishko et al., 2017), while the Central Paratethys developed into the brackish Pannonian Sea (Popov et al., 2004). The connection between different parts of the Paratethyan realm was interrupted at the end of the Middle Miocene, leading to the development of the endemic mammalian megafauna in the Eastern Paratethys.

\section{CONCLUSION}

The Volhynian vertebrate faunal assemblage of the western and northern edges of the Eastern
Paratethys, including the adjoining Fore-Carpathian Basin, is a marine fauna with strong affinities to the synchronous earliest Sarmatian fauna of the Central Paratethys. It shares characteristic Central Paratethyan taxa, although it is less diverse and less abundant. Therefore, the Sarmatian marine fauna of the Eastern Paratethys at least partly originated from the Mediterranean and Paratethyan faunas during Badenian. Marine taxa initially concentrated in the Fore-Carpathian Basin, from where they dispersed eastwards into the Eastern Paratethys during Volhynian and evolved under increasingly isolated conditions. Some of them (e.g. cetotheriid whales) could survive the Badenian/Sarmatian extinction event in the Fore-Carpathian Basin and disperse both westwards and eastwards from that region.

\section{ACKNOWLEDGEMENTS}

All authors have contributed equally. We are thankful to B. Ridush (CNU), M. Bukhsianidze (GNM) and M. Gasparik (HNHM) for their kind help with allowing an access to the collections. L. Godlevska, M. Savchenko and P. Vorobey are acknowledged for help in the field work by PG. The authors thank W. Schwarzhans, D. Palcu, Ş. Vasile, B. Studencka, and an anonymous reviewer for their critical comments to the early draft and suggestions that significantly improved the manuscript. 


\section{REFERENCES}

Anđelković, J. 1962. On the study of Lower Sarmatian fishes of Belgrade. Geološki Anali Balkanskog Poluostrva, 29:115-127.

Anđelković, J.S. 1989. Tertiary fishes of Yugoslavia: A stratigraphic-paleontologicpaleoecological study. Palaeontologia Jugoslavica, 38:1-121.

Bannikov, A.F. 1986. The first discovery of fossil wrasses (Teleostei) in the Sarmatian deposits of Moldavia. Paleontological Journal, 20(1):57-62.

Bannikov, A.F. 1989. The first discovery of scale-bearing blennies (Teleostei) in the Sarmatian of Moldavia. Paleontological Journal, 23(2):59-65.

Bannikov, A.F. 1993. A new species of bass (Teleostei, Moronidae) from the Sarmatian of Moldova. Paleontological Journal, 27(1):54-62.

Bannikov, A.F. 2009. On Early Sarmatian fishes from the Eastern Paratethys. Paleontological Journal, 43(5):569-573. https://doi.org/10.1134/S003103010905013X

Bannikov, A.F. 2010. Fossil acanthopterygian fishes (Teleostei, Acanthopterygii), p. 1-244. In Tatarinov, L.P., Vorobyeva, E.I., and Kurochkin, E.N. (eds.), Fossil Vertebrates of Russia and Adjacent Countries. GEOS, Moscow. (In Russian)

Bannikov, A.F. and Kotlyar, A.N. 2015. A new genus and species of early Sarmatian porgies (Perciformes, Sparidae) from the Krasnodar Region. Paleontological Journal, 49:627-635. https://doi.org/10.1134/S0031030115060052

Baykina, E.M. 2012. A new clupeid genus (Pisces, Clupeiformes, Clupeidae) from the Sarmatian of the Eastern Paratethys, Krasnodar Region. Paleontological Journal, 46:302-312. https:// doi.org/10.1134/S0031030112030057

Baykina, E.M. 2013a. A revision of Clupea doljeana Kramberger and Sarmatella vukotinovici (Kramberger) (Pisces, Clupeidae) from the Sarmatian of Croatia. Paleontological Journal, 47(5):62-71. https://doi.org/10.1134/S0031030113050043

Baykina, E.M. 2013b. Diagnostic importance of visceral skull bones of recent and fossil Clupeinae (Pisces, Clupeidae). Journal of Ichthyology, 53(9):687-701. https://doi.org/ 10.1134/S0032945213050019

Baykina, E.M. and Schwarzhans, W. 2017. Review of "Clupea humilis" from the Sarmatian of Moldova and description of Moldavichthys switshenskae gen. et sp. nov. Swiss Journal of Palaeontology, 136(1):141-149. https://doi.org/10.1007/s13358-016-0121-6

Bogachev, V.V. 1929. Whale and fish remains in diatom deposits of Apsheronski Peninsula. Azerbaidjanskoe neftyanoe khozyaistvo, 77:33-39. (In Russian)

Bogachev, V.V. 1933. Materials on the study of Tertiary ichthyofauna of Caucasus. Trudy AzNII po dobyche nefti, geologicheskyi otdel, 15:1-62. (In Russian)

Bogachev, V.V. 1955. Lower Sarmatian fishes of Amvrosievka. Doklady AN SSSR, 105(3):570572. (In Russian)

Brandt, J.F. 1871. Bericht über den Fortgang meiner Studien über die Cetaceen, welche das grosse zur Tertiärzeit von Mitteleuropa bis Centralasien hinein ausgedehnte Meeresbecken bevölkerten. Bulletin de l'Académie Impériale des Sciences de St.-Pétersbourg, 16:563-566.

Brandt, J.F. 1872. Bericht uber den bereits vollendeten, druckfertigen theil seiner untersuchungen uber die fossilen and subfossilen Cetaceen Europas. Compte Rendu de l'Académie Impériale des Sciences de St Petersbourg, 17:407-408.

Brandt, J.F. 1873. Untersuchungen uber die fossilen und subfossilen Cetaceen Europas. Memoires de l'Academie de St Petersbourg, 20(1):1-371.

Brânzilă, M. 1999. Geologia părţii sudice a Câmpiei Moldovei. Editura Corson, lasi.

Bratishko, A., Kovalchuk, O., and Schwarzhans, W. 2017. Bessarabian (Tortonian, Late Miocene) fish otoliths from a transitional freshwater-brackish environment of Mykhailivka, Southern Ukraine. Palaeontologia Electronica, 20.3.44A:1-13. https://doi.org/10.26879/769

Buchholtz, E.A. 2001. Vertebral osteology and swimming style in living and fossil whales (Order: Cetacea). Journal of Zoology, 253(2):175-190. https://doi.org/10.1017/S0952836901000164

Carnevale, G., Bannikov, A.F., Landini, W., and Sorbini, C. 2006. Volhynian (early Sarmatian sensu lato) fishes from Tsurevsky, North Caucasus, Russia. Journal of Paleontology, 80(4):684-699. https://doi.org/10.1666/0022-3360(2006)80[684:VESSLF]2.0.CO;2 
Chanet, B. and Schultz, O. 1994. Pleuronectiform fishes from the Upper Badenian (Middle Miocene) of St. Margarethen (Austria). Annalen des Naturhistorischen Museums in Wien, 96:95-115.

Chanet, B. and Sorbini, C. 2001. A male fish Bothus podas (Delaroche, 1809)

[Pleuronectiformes: Bothidae] in the Pliocene of the Marecchia river (Italy). Bolletino della Società Paleontologica Italiana, 40:345-350.

Chapleau, F. 1993. Pleuronectiform relationships: A cladistic reassessment. Bulletin of Marine Science, 52:516-540.

Codrea, V. 2006. Neogene baleen whales (Cetacea: Mysticeti) from Transylvania and Oltenia. Oltenia. Studii şi cercetări, Series Geologia-Geographia, 11:7-14.

Codrea, V., Răţoi, B., Hiru, A., and Ursachi, L. 2014. A lower Sarmatian small-sized dolphin (Mammalia: Cetacea, Odontoceti) at Basarabi (Suceava District). Muzeul Olteniei Craiova. Oltenia. Studii şi comunicări. Ştiinţele Naturii, 30:15-20.

Dewaele, L., Lambert, O., and Louwye, S. 2018a. A critical revision of the fossil record, stratigraphy and diversity of the Neogene seal genus Monotherium (Carnivora, Phocidae). Royal Society Open Science, 5(5):171669.

Dewaele, L., Peredo, C.M., Meyvisch, P., and Louwye, S., 2018b. Diversity of late Neogene Monachinae (Carnivora, Phocidae) from the North Atlantic, with the description of two new species. Royal Society Open Science, 5(3):172437. doi:10.1098/rsos.172437

Dombrovsky, B.S. 1927. Two records of fossil cetaceans of the genus Pachyacanthus Brandt at the Caucasus. Trudy Geologicheskogo Muzeya Akademii Nauk SSSR, 2:1-35. (In Russian)

Gol'din, P.E. 2016. Underground whales of Ukraine. Visnyk NAN Ukrainy, 10:51-59. https:// doi.org/10.15407/visn2016.10.051 (In Ukrainian)

Gol'din, P.E. and Radović, P. 2018. A Middle Miocene baleen whale from Bele Vode in Belgrade, Serbia. Rivista Italiana di Paleontologia e Stratigrafia, 124(1):127-138. https://doi.org/ 10.13130/2039-4942/9751

Gol'din, P. and Startsev, D. 2017. A systematic review of cetothere baleen whales (Cetacea, Cetotheriidae) from the Late Miocene of Crimea and Caucasus, with a new genus. Papers in Palaeontology, 3(1):49-68. https://doi.org/10.1002/spp2.1066

Gol'din, P., Startsev, D., and Krakhmalnaya, T. 2014. The anatomy of the Late Miocene baleen whale Cetotherium riabinini from Ukraine. Acta Palaeontologica Polonica, 59(4):795-814. https://doi.org/10.4202/app.2012.0107

Goodrich, E.S. 1930. Studies on the Structure and Development of Vertebrates. Macmillan and Co., London. https://doi.org/10.5962/bhl.title.82144

Gorjanović-Kramberger, D. 1882. Die jungtertiäre Fischfauna Croatiens. Beiträge zur Paläontologie Österreich-Ungarns und des Orients, 2:86-135.

Gorjanović-Kramberger, D. 1884. Die jungtertiäre Fischfauna Croatiens II Theil. Beiträge zur Paläontologie Österreich-Ungarns und des Orients, 3:65-85.

Grasu, C., Miclăuş, C., Brânzilă, M., and Boboş, I. 2002. Sarmaţianul din sistemul bazinelor de foreland ale Carpaţilor Orientali. Editura Tehnică, Bucuresti.

Grigorescu, D. and Kazár, E. 2006. A new Middle Miocene odontocete (Mammalia: Cetacea) locality and the Sarmatian Marine Mammal Event in the Central Paratethys. Oryctos, 6:5367.

Harzhauser, M. and Piller, W.E. 2004. Integrated stratigraphy of the Sarmatian (Upper Middle Miocene) in the western Central Paratethys. Stratigraphy, 1:65-86.

Hensley, D.A. 1977. Larval development of Engyophris senta (Bothidae), with comments on intermuscular bones in flatfishes. Bulletin of Marine Science, 27:681-703.

Hensley, D.A. and Ahlstrom, E.H. 1984. Pleuronectiformes: Relationships, p. 670-687. In Moser, H.G., Richards, W.J., Cohen, D.M., Fahay, M.P., Kendall Jr., A.W., and Richardson, S.L. (eds.), Ontogeny and Systematics of Fishes. American Society of Ichthyologists and Herpetologists, Special Publication 1. Lawrence, Kansas.

Hofstein, I.D. 1965. Materials on fossil cetaceans from the Geological Museum of the USSR Academy of Sciences in Kiev. Paleontologičeskij Sbornik Lvovskogo Gosudarstvennogo Universiteta, 1(2):25-29. (In Russian)

Ionesi, B. 1968. Stratigrafia depozitelor miocene de platformă dintre Valea Siretului şi Valea Sucevei (Platforma Moldovenească). Editura Academiei, Bucuresti.

Ionesi, B. 1991. Biozonarea Sarmaţianului din Platforma Moldovenească. The celebration days of Alexandru Ioan Cuza University of lasi, 25-26(X, 1991):25-26. 
Ionesi, B. and Galan, V. 1988. Contributions à la connaissance des Cétacés fossiles du Sarmatien de la Plate-forme Moldave. Analele ştiinţifice ale Universităţii „Al. I. Cuza” laşi, 34:31-33.

lonko, V.I. 1954. On the find of fossil fishes in lower Sarmatian deposits of MSSR. Trudy Odesskogo Universiteta. Sbornik geologo-geograficheskogo fakulteta, 2:109-119. (In Russian)

Jasionowski, M., Studencka, B., and Poberezhskyy, A. 2006. Wycieczka nr 3. Stop VI Kołubajowce [Kolubaivtsi], p. 89-90. In Wysocka, A. and Jasionowski, M. (eds.), Przebieg I zmienność sedymentacji w basenach przedgórskich. II Polska Konferencja Sedymentologiczna. Instytut Geologii Podstawowej, Wydział Geologii UW, Warszawa.

Kazár, E., 2005. A new kentriodontid (Cetacea: Delphinoidea) from the Middle Miocene of Hungary. Fossil Record, 8(1):53-73.

Kazár, E. 2006. Odontocete periotics (Mammalia: Cetacea) from the Carpathian Basin, Middle Miocene (Badenian and Sarmatian Stages), including the Vienna Basin, Austria. Beiträge zur Paläontologie, 30:269-292.

Kazár, E. 2010. Revision of the genus Pachyacanthus Brandt, 1871 (Mammalia: Cetacea: Odontoceti). Annalen des Naturhistorischen Museums in Wien. Serie A, 112:537-567.

Kellogg, R. 1927. Kentriodon pernix, a Miocene porpoise from Maryland. Proceedings of the United States National Museum, 69(19):1-14.

Kirpichnikov, A.A. 1954. Two new dolphin genera from the Sarmatian of the USSR. Trudy Paleontologicheskogo Instituta AN SSSR, 87:181-190. (In Russian)

Koretsky, I.A. 2001. Morphology and Systematics of Miocene Phocinae (Mammalia: Carnivora) from Paratethys and the North Atlantic Region. Geological Institute of Hungary, Budapest.

Koretsky, I.A. 2003. New finds of Sarmatian seals (Mammalia, Carnivora, Phocinae) from southern Hungary, p. 63-70. In Petculescu, A. and Stiucã, E. (eds.), Advances in Vertebrate Paleontology "Hen to Panta". Institute of Speleology, Bucharest.

Koretsky, I.A. and Grigorescu, D. 2002. The fossil monk seal Pontophoca sarmatica (Alekseev) (Mammalia: Phocidae: Monachinae) from the Miocene of Eastern Europe. Smithsonian Contributions to Paleobiology, 93:149-162.

Koretsky, I.A. and Holec, P. 2002. A primitive seal (Mammalia: Phocidae) from the early middle Miocene of Central Paratethys. Smithsonian Contributions to Paleobiology, 93:163-178.

Kováč, M., Hudáčková, N., Halásová, E., Kováčová, M., Holcová, K., Oszczypko-Clowes, M., Báldi, K., Less, G., Nagymarosy, A., Ruman, A., and Klučiar, T. 2017. The Central Paratethys palaeoceanography: a water circulation model based on microfossil proxies, climate, and changes of depositional environment. Acta Geologica Slovaca, 9:75-114.

Kovalchuk, O., Świdnicka, E., and Stefaniak, K. 2019. A new record of Gobius jarosi (Teleostei, Gobiidae) from the Early Miocene of Poland with inference to paleogeography and palaeoecology of the Carpathian Basin. Historical Biology, 31(10):1394-1401. https://doi.org/ 10.1080/08912963.2018.1457032

Kudrin, L.N. and Tatarinov, K.A. 1966. Miocene dolphins of West Ukraine. International Geology Review, 8(8):976-981. (In Russian)

Lagler, K.F. 1947. Lepidological studies 1. Scale characters of the families of Great Lakes Fishes. Transactions of the American Microscopical Society, 46(2):149-168.

Linnaeus, C. 1758. Systema naturae per regna tria naturae, secundum classes, ordines, genera species, cum characteribus, differentiis, synonymis, locis. T. I. Laurentii Salvii, Holmia.

Macarovici, N. 1947. Cetacés du sarmatien inférieur du nord de la Moldavie et de la Bessarabie. Annales Scientifiques de l'Université de Jassy, 30:133-140.

Macarovici, N. 1970. Asupra unor fosile necunoscute din Miocenul Podişului Moldovenesc. Studii şi Cercetări de Geologie - Geographie, Biologie - Muzeologie. Muzeul de Ştiinţe Naturale Piatra Neamţ, 1:61-66.

Macarovici, N. and Zaharia, N. 1967. Asupra unor mamifere fosile din Sarmaţianul Podişului Moldovenesc. Buletinul Societăţii de Ştiinţe Geologice din RS România, 10:217-227.

Macarovici, N. and Zaharia, N. 1968. Nouvelles données sur quelques Cétacés du Sarmatien inférieur du Nord de la Moldavie. Travaux du Muséum d'Histoire Naturelle Grigore Antipa, 8:1867-1967.

Mchedlidze, G.A. 1964. Fossil Cetaceans of Caucasus. Metsniereba, Tbilisi. (In Russian)

Menner, V.V. 1949. Class Pisces in Zabelin, A.G. (ed.), Atlas rukovodiashchikh form iskopaemykh faun SSSR. Vol. 13: Neogen [Neogene]. Gosgeolitizdat, Moscow. (In Russian) 
Monsch, K.A. and Bannikov, A.F. 2012. New taxonomic synopses and revision of the scombroid fishes (Scombroidei, Perciformes), including billfishes, from the Cenozoic of territories of the former USSR. Earth and Environmental Science Transactions of the Royal Society of Edinburgh, 102:253-300. https://doi.org/10.1017/S1755691011010085

Nordmann, A. 1860. Palaeontologie Suedrusslands. H.C. Friis, Helsingfors.

Oszczypko, N. and Oszczypko-Clowes, M. 2012. Stages of development in the Polish Carpathian Foredeep basin. Central European Journal of Geosciences, 4:138-162.

Paghida Trelea, N. 1969. Microfauna Miocenului dintre Siret şi Prut. Editura Academiei, Bucuresti.

Palcu, D.V., Golovina, L.A., Vernyhorova, Y.V., Popov, S.V., and Krijgsman, W. 2017. Middle Miocene paleoenvironmental crises in Central Eurasia caused by changes in marine gateway configuration. Global and Planetary Change, 158:57-71. https://doi.org/10.1016/ j.gloplacha.2017.09.013

Palcu, D.V., Tulbure, M., Bartol, M., Kouwenhoven, T.J., and Krijgsman, W. 2015. The Badenian-Sarmatian Extinction Event in the Carpathian foredeep basin of Romania: Paleogeographic changes in the Paratethys domain. Global and Planetary Change, 133:346358. https://doi.org/10.1016/j.gloplacha.2015.08.014

Papp, K. 1905. Heterodelphis leiodontus nova forma aus dem miocenen schichten des comitates Sopron in Ungarn. Magyar Királyi Földtani Intézet Évkönyve, 14:23-55.

Paucă, M. 1938. Téléostéens fossiles du Tertiaire Roumain. Comptes Rendus des Sceances de l'Institut de Geologie de Roumanie, 22:1-15.

Peabody, E.B. 1928. The scales of some fishes of the suborder Clupeoidei. University of Colorado Studies, 16:127-148.

Perrin, W.F. 1984. Patterns of geographical variation in small cetaceans. Acta Zoologica Fennica, 172:134-140.

Popov, S.V., Rögl, F., Rozanov, A.Y., Steininger, F.F., Shcherba, I.G., and Kováč, M. 2004. Lithological paleogeographic maps of Paratethys. 10 maps from Late Eocene to Pliocene. Courier Forschungsinstitut Senckenberg, 250:1-46.

Rafinesque, C.S. 1810. Indice d'Ittiologia Siciliana; ossia, catalogo metodico dei nomi latini, italiani, e siciliani dei pesci, che si rinvengono in Sicilia disposti secondo un metodo naturale e seguito da un'appendice che contiene la descrizione di alcuni nuovi pesci siciliani. Presso Giovanni del Nobolo, Messina.

Rögl, F. 1998. Palaeogeographic considerations for Mediterranean and Paratethys seaways. Annalen des Naturhistorischen Museums in Wien, 99A:279-310.

Rückert-Ülkümen, N. 1960. Tertiäre Fische aus Thrakien und Dardanellen (Türkei). Revue de la Faculté des Sciences de l'Université d'Istanbul, Série B, 28:65-108.

Rückert-Ülkümen, N. 1965. Fossile Fische aus dem Sarmat von Pinarhisar (Türkish Thrakien). Senckenbergiana Lethaea, 46:315-361.

Sant, K., Palcu, D.V., Mandic, O., and Krijgsman, W. 2017. Changing seas in the Early-Middle Miocene of Central Europe: a Mediterranean approach to Paratethyan stratigraphy. Terra Nova, 29(5):273-281.

Schneider, S., Mandic, O., and Harzhauser, M. 2013. Preserved colour pattern in Polititapes tricuspis (Eichwald, 1829) (Bivalvia: Veneridae) from the Sarmatian holostratotype at Nexing (Lower Austria). Neues Jahrbuch für Geologie und Paläontologie - Abhandlungen, 268/ 2:191-197. https://doi.org/10.1127/0077-7749/2013/0326

Schwarzhans, W., Carnevale, G., Bannikov, A.F., Japundžić, S., and Bradić, K. 2017a. Otoliths in situ from Sarmatian (Middle Miocene) fishes of the Paratethys. Part I: Atherina suchovi Switchenska 1973. Swiss Journal of Palaeontology, 136:7-17. https://doi.org/10.1007/ s13358-015-0111-0

Schwarzhans, W., Carnevale, G., Bratishko, A., Japundžić, S., and Bradić, K. 2017b. Otoliths in situ from Sarmatian (Middle Miocene) fishes of the Paratethys. Part II: Gadidae and Lotidae. Swiss Journal of Palaeontology, 136:19-43. https://doi.org/10.1007/s13358-016-0114-5

Schwarzhans, W., Ahnelt, H., Carnevale, G., Japundžić, S., Bradić, K., and Bratishko, A. 2017c. Otoliths in situ from Sarmatian (Middle Miocene) fishes of the Paratethys. Part III: tales from the cradle of the Ponto-Caspian gobies. Swiss Journal of Palaeontology, 136:45-92. https:// doi.org/10.1007/s13358-016-0120-7

Schwarzhans, W., Carnevale, G., Japundžić, S., and Bradić-Milinović, K. 2017d. Otoliths in situ from Sarmatian (Middle Miocene) fishes of the Paratethys. Part V: Bothidae and Soleidae. Swiss Journal of Palaeontology, 136:109-127. https://doi.org/10.1007/s13358-017-0128-7 
Shackell, N.L., Frank, K.T., Fisher, J.A.D., Petrie, B., and Leggett, W.C. 2010. Decline in top predator body size and changing climate alter trophic structure in an oceanic ecosystem. Proceedings of the Royal Society B, 277:1353-1360. https://doi.org/10.1098/rspb.2009.1020

Studencka, B. 1999. Remarks on Miocene bivalve zonation in the Polish part of the Carpathian Foredeep. Geological Quarterly, 43:467-477.

Szymczyk, W. 1978. Clupeid scales from the Menilite Beds (Palaeogene) of the Carpathians. Acta Palaeontologica Polonica, 23:387-407.

Šoster, A. and Kovalchuk, O.M. 2016. Late Neogene and Pleistocene porgy fishes (Teleostei, Sparidae) of the Eastern Paratethys, with comments on their palaeoecology. Vestnik zoologii, 50(5):415-422. https://doi.org/10.1515/vzoo-2016-0048

Tarashchuk, V.I., 1957. Remains of seabream (Pagellus, fam. Sparidae, Pisces) from Neogene deposits of Ternopil Oblast. Dopovidi Akademii Nauk Ukrainskoi RSR, 5:619-623. [Ukrainian].

Tatarinov, K.A. 2000. Late Cenozoic vertebrates of western Ukraine (localities, systematic, paleoecology). Lutsk. (In Russian)

Ter Borgh, M., Stoica, M., Donselaar, M.E., Matenco, L., and Krijgsman, W. 2014. Miocene connectivity between the Central and Eastern Paratethys: Constraints from the western Dacian Basin. Palaeogeography, Palaeoclimatology, Palaeoecology, 412:45-67. https:// doi.org/10.1016/j.palaeo.2014.07.016

Ţibuleac, P. 2009. Sarmaţianul cu strate de cărbuni din zona Fălticeni-Boroaia (Platforma Moldovenească). Editura Tehnopress, Iaşi.

Van Beneden, P.J. 1884. Une Baleine fossile de Croatie, appartenant au genre Mésocète (avec 2 planches). Mémoires de l'Académie Royale des Sciences, des Lettres et des Beaux-Arts de Belgique, 45:1-29.

Vernyhorova, Y. 2015. Stratigraphic scheme for the Neogene deposits of the Northern Black Sea region and adjacent part of the Ukrainian Shield. Heolohiia ta rudonosnist Ukrainy, 1:81-124. (In Ukrainian) 


\section{SUPPLEMENTARY MATERIAL}

Tables available as PDF for download.

TABLE S1. Age summary of the studied localities.

TABLE S2. Marine vertebrate records from the Volhynian of the Eastern Paratethys (western and northern part) by taxon, locality and age.

TABLE S3. List of specimens used in this study. 